\title{
Uji aktivitas antibakteri ekstrak daun mayana jantan (Coleus atropurpureus Benth) terhadap pertumbuhan bakteri Streptococcus Sp. dan Pseudomonas Sp.
}

\author{
${ }^{1}$ Patrick Muljono \\ ${ }^{2}$ Fatimawali \\ ${ }^{2}$ Aaltje E. Manampiring
}

\author{
${ }^{1}$ Kandidat Skripsi Fakultas Kedokteran Universitas Sam Ratulangi \\ ${ }^{2}$ Bagian Kimia Fakultas Kedokteran Universitas Sam Ratulangi \\ Email: muljonopatrick@gmail.com
}

\begin{abstract}
The painted nettle (Coleus atropurpureus benth) is a plant that is known to have medicinal properties, especially the leaf. The active compounds that are contained in the leafs are thought to work as an antibacterial. This study aims to measure the inhibitory strength of painted nettle leaf (Coleus atropurpureus benth) extract against the growth of Streptococcus $s p$. and Pseudomonas sp. This was an experimental laboratory study. The polar extract of painted nettle leaf (Coleus atropurpureus benth) was tested by well method with concentrations of $100 \%, 80 \%, 60 \%, 40 \%$ and $20 \%$. The polar extract of painted nettle leaf (Coleus atropurpureus benth) is the result of extraction of painted nettle that has been dried and then macerated using ethanol as the polar solvent. Tests were conducted to observe whether there is a zone of inhibition of polar extract of the painted nettle leaf (Coleus atropurpureus benth) against Streptococcus sp. and Pseudomonas sp. after 24 hours of incubation. Results show that the polar extract of painted nettle leaf (Coleus atropurpureus benth) with concentrations of $100 \%, 80 \%, 60 \%, 40 \%$ and $20 \%$ are able to inhibit the growth of Streptococcus sp. with an average of each concentration $12.8 \mathrm{~mm}, 11.17 \mathrm{~mm}, 8.67 \mathrm{~mm}$, $3.17 \mathrm{~mm}$ and $2 \mathrm{~mm}$ respectively while against Pseudomonas $s p$. with a mean diameter of each inhibition zone is $12.17 \mathrm{~mm}, 10.67 \mathrm{~mm}, 9.5 \mathrm{~mm}, 7.17$ and $5.17 \mathrm{~mm}$ respectively. Conclusion: The polar extract of painted nettle leaf (Coleus atropurpureus benth) has an inhibitory effect against the growth of Streptococcus sp. and Pseudomonas sp.
\end{abstract}

Keywords: coleus atropurpureus benth, inhibition, streptococcus sp,pseudomonas sp.

\begin{abstract}
Abstrak: Tumbuhan mayana jantan (Coleus atropurpureus benth) merupakan salah satu tanaman yang dikenal berkhasiat sebagai obat terutama bagian daunnya, senyawa aktif yang terkandung dalam daun mayana jantan mampu bekerja sebagai antibakteri. Penelitian ini bertujuan untuk mengukur dan mengetahui ada tidaknya daya hambat ekstrak daun mayana jantan (Coleus atropurpureus benth) terhadap pertumbuhan bakteri Streptococcus sp. dan Pseudomonas sp. Jenis penelitian yang digunakan adalah eksperimental laboratorik. Kadar ekstrak polar mayana jantan (Coleus atropurpureus benth) yang diujikan dengan metode sumuran adalah 100\%, 80\%, 60\%, 40\% dan 20\%. Ekstrak polar daun mayana jantan (Coleus atropurpureus benth) merupakan hasil ekstraksi daun mayana jantan yang telah dikeringkan lalu dimaserasi menggunakan pelarut polar etanol. Uji dilakukan untuk mengamati ada tidaknya zona hambat dari ekstrak polar daun mayana jantan (Coleus atropurpureus benth) terhadap bakteri Streptococcus sp. dan Pseudomonas sp. setelah 24 jam inkubasi. Hasil penelitian menunjukkan ekstrak polar daun mayana jantan (Coleus atropurpureus benth) dengan konsentrasi $100 \%, 80 \%, 60 \%$, 40\% dan 20\% dapat menghambat pertumbuhan bakteri Streptococcus sp. dengan rerata masing-masing yaitu $12,8 \mathrm{~mm}, 11,17 \mathrm{~mm}, 8,67 \mathrm{~mm}, 3,17 \mathrm{~mm}$ dan $2 \mathrm{~mm}$ sedangkan Pseudomonas sp dengan masing-masing rerata diameter zona hambat yaitu 12,17mm, 10,67mm, 9,5mm, 7,17 dan 5,17mm. Simpulan: Ekstrak polar daun mayana
\end{abstract}


jantan (Coleus atropurpureus benth) mempunyai daya hambat terhadap pertumbuhan bakteri Streptococcus sp. dan Pseudomonas sp.

Kata kunci: coleus atropurpureus benth, daya hambat, streptococcus sp,pseudomonas sp.

Obat tradisional merupakan warisan budaya bangsa yang perlu terus dilestarikan dan dikembangkan guna menunjang pembangunan kesehatan sekaligus untuk meningkatkan perekonomian rakyat. Produksi, dan penggunaan obat tradisional di negara Indonesia memperlihatkan kecenderungan terus meningkat, baik jenis maupun volumenya. Perkembangan ini telah mendorong pertumbuhan usaha di bidang obat tradisional, mulai dari usaha budidaya tanaman obat, usaha industri obat tradisional, penjaja dan penyeduh obat tradisional atau jamu. Bersamaan itu upaya pemanfaatan obat tradisional dalam pelayanan kesehatan formal juga terus digalakkan melalui berbagai kegiatan uji klinik kearah pengembangan fito farmaka. ${ }^{1}$

Penyakit infeksi masih merupakan jenis penyakit yang paling banyak diderita oleh penduduk di negara berkembang, termasuk Indonesia. Salah satu penyebab penyakit infeksi adalah bakteri. Bakteri merupakan mikroorganisme yang tidak dapat dilihat dengan mata telanjang, tetapi hanya dapat dilihat dengan bantuan mikroskop. ${ }^{2}$ Bakteri patogen lebih berbahaya dan menyebabkan infeksi baik secara sporadik maupun endemik. ${ }^{3}$

Tanaman mayana jantan (Coleus atropurpureus benth) merupakan tanaman hias yang dapat dimanfaatkan sebagai obat tradisional untuk menobati penyakit infeksi yang berasal dari Asia Tenggara. Corak, bentuk dan warna mayana beranekaragam, tetapi yang berkhasiat obat adalah daun yang berwarna merah kecoklatan. ${ }^{4}$ Tanaman mayana jantan (Coleus atropurpureus benth) mengandung senyawa- senyawa yang berkhasiat sebagai antibakteri, diare, bisul, infeksi telinga, wasir maupun sebagai penambah nafsu makan. ${ }^{5}$

\section{METODE PENELITIAN}

Penelitian ini merupakan penelitian eksperimental laboratorik sedangkan rancangan penelitian yang digunakan adalah rancangan acak lengkap (RAL) dengan 7 perlakuan dan setiap perlakuan terdiri atas 3 ulangan. Lokasi penelitian berada di Laboratorium Mikrobiologi Farmasi Fakultas MIPA, Universitas Sam Ratulangi Manado. Populasi dalam penelitian ini digunakan daun dari tanaman mayana jantan sedangkan sampel yang digunakan adalah daun mayana jantan yang dipetik di kaki gunung Klabat, kelurahan Klabat, kecamatan Dimembe, kabupaten Minahasa Utara, provinsi Sulawesi Utara, Indonesia. Alat alat yang digunakan antara lain : ayakan mesh 65, rotary evaporator, inkubator, laminair air flow, dan autoklaf. Bahan-bahan yang digunakan antara lain : daun Coleus atropurpureus Benth, bakteri uji (Streptococcus sp. dan Pseudomonas sp.) yang diperoleh dari Laboratorium Mikrobiologi Farmasi Fakultas MIPA, Universitas Sam Ratulangi Manado, Carboxy Methyl Cellulose (CMC), aquades steril, etanol 95\% p.a, tablet Ciprofloxacin 500 mg, Nutrient Agar (NA), $\mathrm{H}_{2} \mathrm{SO}_{4}$ 0,36 $\mathrm{N}, \mathrm{BaCl}_{2}, 2 \mathrm{H}_{2} \mathrm{O} 1,175 \%$, NaCl 0,9\%, dan kertas saring no.1. Variabel Penelitian yang diteliti yaitu :

1. Bakteri Streptococcus sp.

2. Bakteri Pseudomonas sp.

3. Ekstrak polar daun mayana jantan

\section{Persiapan Sampel}

Daun mayana yang telah dikumpulkan dibersihkan dari pengotor, selanjutnya dicuci di bawah air mengalir sampai bersih, ditiriskan, lalu dikeringkan dengan cara diangin-anginkan. Sampel yang telah kering diserbukkan dengan menggunakan blender, serbuk yang dihasilkan diayak menggunakan ayakan mesh 65 hingga diperoleh serbuk yang halus dan seragam. Hasilnya dimasukkan ke dalam wadah gelas tertutup. ${ }^{6}$ 


\section{Pembuatan Ekstrak}

Ekstrak daun mayana dibuat dengan cara maserasi. Sebanyak 60 gram serbuk simplisia daun mayana dimasukkan ke dalam erlenmeyer, kemudian direndam dengan larutan etanol 95\% p.a sebanyak 225 $\mathrm{ml}$, ditutup dengan aluminium foil dan dibiarkan selama 5 hari sambil sesekali diaduk. Setelah 5 hari, sampel yang direndam tersebut disaring menggunakan kertas saring menghasilkan filtrat 1 dan ampas 1. Ampas yang ada kemudian ditambah dengan larutan etanol 95\% p.a sebanyak $75 \mathrm{ml}$, ditutup dengan aluminium foil dan dibiarkan selama 2 hari sambil sesekali diaduk. Setelah 2 hari, sampel tersebut disaring menggunakan kertas saring menghasilkan filtrat 2 dan ampas 2 . Filtrat 1 dan 2 dicampur menjadi satu, lalu dievaporasi menggunakan rotary evaporator, sehingga diperoleh ekstrak kental daun mayana. Ekstrak kental yang dihasilkan dibiarkan pada suhu ruangan hingga seluruh pelarut etanol menguap. Ekstrak ditimbang dan disimpan dalam wadah gelas tertutup sebelum digunakan untuk pengujian.

\section{Sterilisasi Alat}

Alat-alat yang digunakan dalam penelitian aktivitas antibakteri ini disterilkan terlebih dahulu. Alat-alat gelas disterilkan dalam oven pada suhu $170^{\circ} \mathrm{C}$ selama \pm 2 jam, jarum ose dan pinset dibakar dengan pembakaran diatas api langsung dan media disterilkan dalam autoklaf pada suhu $121^{\circ} \mathrm{C}$ selama 15 menit. $^{7}$

\section{Pembuatan Larutan Kontrol Negatif}

Kontrol negatif dibuat dari CMC 1\% dengan cara : 1 gram serbuk CMC dilarutkan dalam $100 \mathrm{ml}$ aquades steril, lalu dikocok sampai larutan homogen.

\section{Pembuatan Larutan Kontrol Positif}

Kontrol positif dibuat dari sediaan obat tablet Ciprofloxacin $500 \mathrm{mg}$. Satu tablet Ciprofloxacin digerus, lalu ditimbang dan disetarakan dengan 500 mg. Kemudian serbuk Ciprofloxacin dilarutkan dalam larutan CMC untuk memperoleh larutan Ciprofloxacin $50 \mathrm{M}-\mathrm{g} / 50 \wedge \mathrm{l}$.

\section{Pembuatan Larutan Uji}

Dibuat larutan uji 20\%, 40\%, 60\%, $80 \%$, dan $100 \% \mathrm{~b} / \mathrm{v}$ dengan cara ditimbang 0,2 g; 0,4 g; 0,6 g; 0,8 g; dan 1 g ekstrak etanol daun mayana kemudian masingmasing dilarutkan dalam $1 \mathrm{ml}$ larutan CMC.

\section{Pembuatan Media}

a. Media agar miring dibuat dengan cara melarutkan Nutrient Agar (NA) sebanyak 0,46 gram dalam $20 \mathrm{ml}$ aquades (23 $\mathrm{g} / 1000 \mathrm{ml}$ ) menggunakan erlenmeyer. Setelah itu dihomogenkan dengan stirer diatas penangas air sampai mendidih. Sebanyak $5 \mathrm{ml}$ dituangkan masingmasing pada 3 tabung reaksi steril dan ditutup dengan aluminium foil. Media tersebut disterilkan dalam outoklaf pada suhu $121^{\circ} \mathrm{C}$ selama 15 menit, kemudian dibiarkan pada suhu ruangan selama \pm 30 menit sampai media memadat pada kemiringan $30^{\circ}$. Media Agar miring digunakan untuk inokulasi bakteri.

b. Media dasar dibuat dengan cara ditimbang Nutrient Agar (NA) sebanyak 2,3 gram, lalu dilarutkan dalam $100 \mathrm{ml}$ aquades (23 g/1000 ml) menggunakan erlenmeyer. Sedangkan media pembenihan dibuat dengan cara ditimbang 5,75 gram NA, lalu dilarutkan dalam $250 \mathrm{ml}$ aquades $(23 \mathrm{~g} / 1000 \mathrm{ml})$ menggunakan erlenmeyer. Setelah itu, masing-masing media dihomogenkan dengan stirer diatas penangas air sampai mendidih. Media- media yang sudah homogen ini disterilkan dalam autoklaf pada suhu $121^{\circ} \mathrm{C}$ selama 15 menit, kemudian didinginkan sampai suhu \pm 45$50^{\circ} \mathrm{C}$. Media dasar dan media pembenihan digunakan dalam pembuatan media pengujian sebagai lapisan dasar dan lapisan kedua.

\section{Inokulasi Bakteri pada Media Agar Miring}

Bakteri uji diambil dengan jarum ose steril, lalu ditanamkan pada media agar 
miring dengan cara menggores. Selanjutnya diinkubasi dalam inkubator pada suhu $37^{\circ} \mathrm{C}$ selama 24 jam. Perlakuan yang sama dilakukan pada setiap jenis bakteri uji. ${ }^{8}$

\section{Pembuatan Standar Kekeruhan Larutan (Larutan McFarland)}

Larutan $\mathrm{H}_{2} \mathrm{SO}_{4}$ 0,36 $\mathrm{N}$ sebanyak 99,5 $\mathrm{ml}$ dicampurkan dengan larutan $\mathrm{BaCl}_{2} \cdot 2 \mathrm{H}_{2} \mathrm{O} 1,175 \%$ sebanyak $0,5 \mathrm{ml}$ dalam erlenmeyer. Kemudian dikocok sampai terbentuk larutan yang keruh. Kekeruhan ini dipakai sebagai standar kekeruhan suspensi bakteri uji. ${ }^{9}$

\section{Pembuatan Suspensi Bakteri Uji}

Bakteri uji yang telah diinokulasi diambil dengan kawat ose steril lalu disuspensikan kedalam tabung yang berisi 2 ml larutan $\mathrm{NaCl}$ 0,9\% hingga di peroleh kekeruhan yang sama dengan standar kekeruhan larutan Mc. Farland. Perlakuan yang sama dilakukan pada setiap jenis bakteri uji.

\section{Pembuatan Media Pengujian}

Lapisan dasar dibuat dengan menuangkan masing-masing $10 \mathrm{ml}$ NA dari media dasar ke dalam 9 cawan petri, lalu dibiarkan sampai memadat. Setelah memadat, pada permukaan lapisan dasar diletakkan 7 pencadang baja yang diatur sedemikian rupa jaraknya agar daerah pengamatan tidak saling bertumpuh. Kemudian, suspensi bakteri dicampurkan ke dalam media pembenihan NA. Setelah itu, dituangkan $25 \mathrm{ml}$ campuran suspensi dan media pembenihan tersebut ke dalam tiap cawan petri yang diletakkan pencadang sebagai lapisan kedua. Selanjutnya, pencadang diangkat secara aseptik dari cawan petri, sehingga akhirnya terbentuklah sumur-sumur yang akan digunakan dalam uji antibakteri.

\section{Uji Aktivitas Antibakteri secara In-vitro}

Larutan uji ekstrak etanol daun mayana dengan berbagai konsentrasi (20\%, 40\%, 60\%, 80\% dan 100\%); larutan CMC 1\% sebagai kontrol negatif; larutan
Ciprofloxacin $50 \wedge \mathrm{g} / 50 \wedge \mathrm{l}$ sebagai kontrol positif, masing-masing diteteskan pada sumur yang berbeda sebanyak $50 \wedge \mathrm{l}$. Kemudian cawan petri diinkubasi dalam inkubator pada suhu $37^{\circ} \mathrm{C}$ selama 1 x24 jam.

\section{Pengamatan dan Pengukuran}

Pengamatan dilakukan setelah 1x24 jam masa inkubasi. Daerah bening merupakan petunjuk kepekaan bakteri terhadap antibiotik atau bahan antibakteri lainnya yang digunakan sebagai bahan uji yang dinyatakan dengan lebar diameter zona hambat. Diameter zona hambat diukur dalam satuan milimeter (mm) menggunakan mistar berskala dengan cara diameter keseluruhan dikurangi diameter sumuran $7 \mathrm{~mm}$. Kemudian diameter zona hambat tersebut dikategorikan kekuatan daya antibakterinya berdasarkan penggolongan Davis and Stout. ${ }^{10}$

\section{Pengumpulan Data}

a. Data Primer

Data yang diperoleh dari penelitian secara langsung dengan cara menganalisa aktivitas anti Streptococcus sp. dan Pseudomonas sp. Data ini merupakan data hasil pemeriksaan laboratorium.

b. Data Sekunder

Data sekunder adalah data yang diperoleh dari biakkan bakteri yang sudah tersedia di Laboratorium Bioteknologi Fakultas MIPA Universitas Sam Ratulangi.

\section{HASIL PENELITIAN}

\section{Hasil Ekstraksi Daun Mayana Jantan (Coleus atropurpureus benth)}

Ekstrak daun mayana jantan yang diperoleh melalui proses ekstraksi menggunakan pelarut etanol 95\%. Ekstraksi menggunakan pelarut etanol dipilih dengan maksud untuk mendapatkan bahan aktif polar. Etanol 95\% dipilih sebagai pelarut atau ekstraktor karena melalui serangkaian uji coba awal didapatkan bahwa etanol menunjukkan efek yang paling baik tarhadap penarikan bahan aktif yang terkandung dalan daun mayana jantan.

Ekstrak yang diperoleh kemudian 
disaring dengan kertas saring lalu diuapkan pada tekanan vakum, hasil yang diperoleh memiliki sifat fisik dari ekstrak yaitu berupa endapan yang sangat kental, yang menandakan bahwa tingkat viskositasnya sangat tinggi serta berwarna hijau tua.

\section{Hasil Pengujian Efek Ekstrak Daun Mayana Jantan (Coleus atropurpureus benth)}

Hasil pengujian efek ekstrak polar daun mayana jantan terhadap aktivitas pertumbuhan Streptococcus sp. dan
Pseudomonas sp. pada pengamatan sesudah 24 jam inkubasi dengan 3 kali pengulangan. Hasil pengujian ekstrak polar daun mayana jantan terhadap aktivitas pertumbuhan Streptococcus sp. dan Pseudomonas sp. memiliki nilai positif. Hal ini ditunjukkan dengan adanya wilayah terang disekitar lubang kultur Streptococcus sp. dan Pseudomonas sp. Terdapat juga daya hambat terhadap antibiotik pembanding. Daya hambat aquades menunjukkan hasil negatif.

Tabel 1. Diameter Zona Hambat Ekstrak Daun Mayana Jantan (Coleus atropurpureus benth) Terhadap Pertumbuhan Streptococcus sp. setelah 24 jam inkubasi

\begin{tabular}{ccccccc}
\hline \multirow{2}{*}{ No. } & Cuplikan $(50 \mu \mathrm{l})$ & \multicolumn{2}{c}{ Zona Hambat Ulangan Ke- $(\mathrm{mm})$} & Total & $\begin{array}{c}\text { Rataan } \\
(\mathrm{mm})\end{array}$ \\
\hline 1. & Aquades & 1 & 2 & 3 & 3 & 1 \\
2. & Larutan Ekstrak 20\% & 2,5 & 1,5 & 2 & 6 & 2 \\
3. & Larutan Ekstrak 40\% & 4 & 3 & 2,5 & 9,5 & 3,17 \\
4. & Larutan Ekstrak 60\% & 8 & 10 & 8 & 26 & 8,67 \\
5. & Larutan Ekstrak 80\% & 10,5 & 12,5 & 10,5 & 33,5 & 11,17 \\
6. & Larutan Ekstrak 100\% & 12 & 14 & 12,5 & 38,5 & 12,8 \\
7. & Ciprofloxacin & 19 & 20,5 & 18 & 57,5 & 19,17 \\
\hline
\end{tabular}

Tabel 2. Diameter Zona Hambat Ekstrak Daun Mayana Jantan (Coleus atropurpureus benth) Terhadap Pertumbuhan Pseudomonas sp. setelah 24 jam inkubasi

\begin{tabular}{|c|c|c|c|c|c|c|}
\hline \multirow[b]{2}{*}{ No. } & \multirow{2}{*}{ Cuplikan $(50 \mu l)$} & \multicolumn{3}{|c|}{ Zona Hambat Ulangan Ke- (mm) } & \multirow{2}{*}{ Total } & \multirow{2}{*}{$\begin{array}{l}\text { Rataan } \\
\text { (mm) }\end{array}$} \\
\hline & & 1 & 2 & 3 & & \\
\hline 1. & Aquades & 1 & 1 & 1 & 3 & 1 \\
\hline 2. & Larutan Ekstrak 20\% & 5 & 4 & 6,5 & 15,5 & 5,17 \\
\hline 3. & Larutan Ekstrak 40\% & 6,5 & 7 & 8 & 21,5 & 7,17 \\
\hline 4. & Larutan Ekstrak 60\% & 9 & 9,5 & 10 & 28,5 & 9,5 \\
\hline 5. & Larutan Ekstrak 80\% & 9,5 & 11 & 11,5 & 32 & 10,67 \\
\hline 6. & Larutan Ekstrak 100\% & 12 & 12 & 12,5 & 36,5 & 12,17 \\
\hline 7. & $\begin{array}{l}\text { Ciprofloxacin } \\
(50 \mu \mathrm{l} / 100 \mu \mathrm{g})\end{array}$ & 24,5 & 20,5 & 21,5 & 66,5 & 22,17 \\
\hline
\end{tabular}

Tabel 3 memperlihatkan rerata diameter zona hambat dari aquades, larutan uji ekstrak daun mayana jantan (Coleus atropurpureus benth) dengan konsentrasi 20\%, 40\%, 60\%, 80\%, 100\%, dan larutan ciprofloxacin terhadap aktivitas pertumbuhan Streptococcus sp. dan
Pseudomonas sp. setelah inkubasi 24 jam. Gambar 2 menampilkan kurva hasil pengamatan 24 jam inkubasi terhadap uji aktivitas antimikroba. Dapat dilihat kurvakurva hubungan antara dosis efek dari aquades, larutan uji ekstrak daun mayana jantan (Coleus atropurpureus benth) 
Muljono, Fatimawali, Manampiring: Uji aktivitas antibakteri...

konsentrasi 20\%, 40\%, 60\%, 80\%, 100\%, dan larutan ciprofloxacin dengan rataan pertumbuhan Streptococcus sp. dan lebar diameter terukur zona hambat Pseudomonas sp.

Tabel 3. Rataan Zona Hambat Ekstrak Daun Mayana jantan (Coleus atropurpureus benth) Terhadap Pertumbuhan Streptococcus sp. dan Pseudomonas sp. setelah 24 jam inkubasi

\begin{tabular}{cccc}
\hline & & Diameter Daerah hambat setelah 24 jam inkubasi \\
No. & Bahan Uji & Streptococcus sp. & Pseudomonas sp. \\
\hline 1. & Aquades & 1 & 1 \\
2. & Larutan Ekstrak 20\% & 2 & 5,17 \\
3. & Larutan Ekstrak 40\% & 3,17 & 7,17 \\
4. & Larutan Ekstrak 60\% & 8,67 & 9,5 \\
5. & Larutan Ekstrak 80\% & 11,17 & 10,67 \\
6. & Larutan Ekstrak 100\% & 12,8 & 12,17 \\
7. & Ciprofloxacin & 19,17 & 22,17 \\
\hline
\end{tabular}

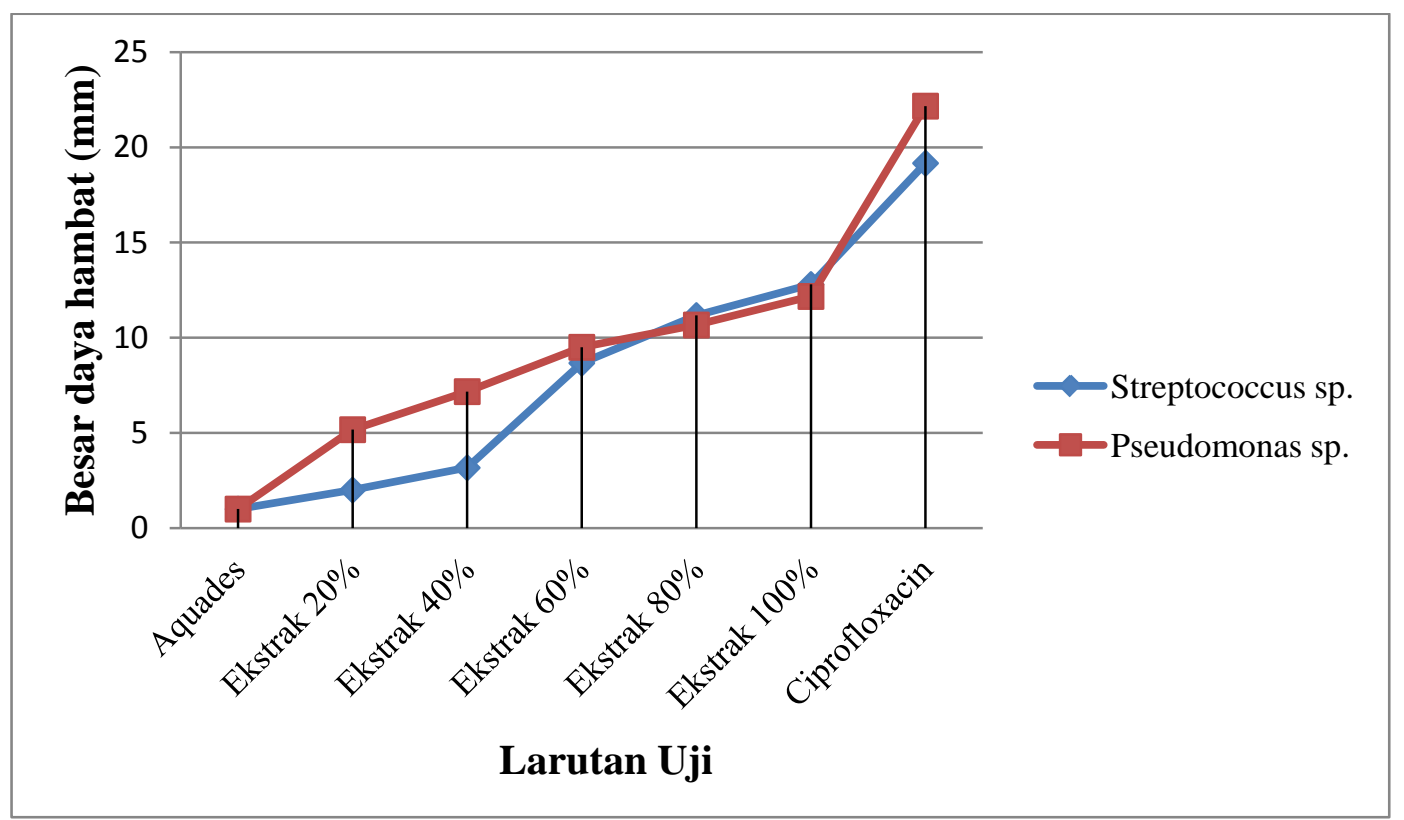

Gambar 1. Kurva Perbandingan Zona Hambat Ekstrak Daun Mayana Jantan (Coleus atropurpureus benth) Terhadap Pertumbuhan Streptococcus sp. dan Pseudomonas sp. setelah 24 jam inkubasi

\section{BAHASAN}

Pada penelitian ini dibuat ekstrak dari daun mayana jantan dengan larutan ekstraktor etanol yang bersifat ekstraktor polar. ${ }^{10}$ Artinya bahan berkhasiat yang terbukti mempunyai kemampuan antimikroba dari daun mayana jantan (Coleus atropurpureus benth) sifatnya adalah polar. Prinsip dasar penelitian adalah ekstrak polar daun mayana jantan (Coleus atropurpureus benth) dapat menghambat pertumbuhan Streptococcus sp. dan Pseudomonas sp. Penetesan ekstrak polar daun mayana jantan (Coleus atropurpureus benth) kedalam lubang yang dibuat pada permukaan lapisan pembenihan bakteri adalah untuk melihat apakah dengan penambahan ekstrak polar daun mayana jantan dapat terjadi penghambatan pertumbuhan bakteri. Penghambatan 
pertumbuhan bakteri dapat terlihat dengan adanya zona terang disekitar lubang.

Penggunaan beberapa konsentrasi ekstrak polar daun mayana jantan, 20\%, 40\%, 60\%, 80\%, dan 100\% dimaksudkan agar dapat dibuktikan ada tidaknya bukan saja aktivitas antimikroba terhadap bakteri uji, tetapi untuk membuktikan ada tidaknya efek farmakologi yang dimiliki ekstrak polar daun mayana jantan. Bakteri uji yaitu Streptococcus sp. dan Pseudomonas sp.

Dalam penelitian ini tidak dilakukan uji kesetaraan dosis atau dalam hal hubungan efek antimikroba dengan massa berat substansi bahan berkhasiat aktif dari serbuk misalnya uji kesetaraan dengan ciprofloxacin 50 $\mathrm{\mu g}$ dimana memerlukan penelitian fitokimia seperti dengan kromatografi lapis tipis dengan uji efek dari nokta atau spot kromatogram yang berefek antimikroba. $^{11}$

Metode sumur modifikasi dari metode Kirby Bauer digunakan karena metode ini lebih cocok dan praktis untuk uji obat daripada metode difusi menggunakan cakram. Dimana dengan cakram, volume larutan uji sngat terbatas. Volume cuplikan yang lebih dari $20 \mu \mathrm{l}$ per cakram sudah mengakibatkan gangguan pengamatan dan pengukuran.

Penggunaan aquades sebagai control negatif adalah mutlak untuk menyingkirkan kemungkinan adanya efek antimikroba. Pada hasil pengamatan, ternyata untuk semua sumur dengan aquades tidak ada satupun yang memberikan zona hambat (tabel 1-3).

Penggunaan larutan pembanding antimikroba baku yaitu ciprofloxacin sebagai kontrol positif merupakan pembanding efek antara obat antimikroba baku tersebut dengan larutan ekstrak uji dalam hal ini ekstrak daun mayana jantan.

Ciprofloxacin dengan dosis $50 \mu \mathrm{l}$ per sumur memperlihatkan kekuatan efek antimikroba terhadap Streptococcus sp. dan Pseudomonas sp. pada 24 jam inkubasi. Lebar diameter zona hambat pada dosis ini sangat menonjol besarnya dibandingkan dengan lebar diameter zona hambat larutan- larutan uji.

Pengamatan pada bakteri uji Streptococcus sp. (tabel 1), menunjukkan bahwa aquades sebagai control negatif tidak memiliki daya hambat terhadap pertumbuhan Streptococcus sp., yang ditunjukkan dengan tidak adanya zona hambat pada daerah sekitar sumur yang berisi aquades tersebut. Larutan pembanding ciprofloxacin 50 $\mathrm{g} / 50 \mu \mathrm{l}$ memiliki zona hambat yang besar terhadap pertumbuhan Streptococcus sp.

Pada Tabel 1, larutan uji daun mayana jantan konsentrasi 20\% telah menunjukkan adanya efek penghambatan terhadap pertumbuhan Streptococcus sp. Efek ini makin kuat pada konsentrasi $40 \%, 60 \%$, 80\%, 100\% (Tabel 1).

Efek antimikroba ternyata makin meningkat dengan adanya peningkatan konsentrasi larutan uji berturut-turut dari $20 \%, 40 \%$, 60\%, 80\%, 100\%. Hal ini menunjukkan bahwa ada hubungan positif kuat antara konsentrasi dan zona hambat. Hubungan ini dapat dilihat pada gambar 2 . Artinya, larutan ekstrak daun mayana jantan dengan ekstraktor etanol memiliki efek antimikroba terhadap Streptococcus sp.

Pengamatan terhadap pertumbuhan bakteri Pseudomonas sp. sesuai tabel 2 menunjukkan bahwa aquades sebagai kontrol negative tidak memiliki efek penghambatan terhadap pertumbuhan Pseudomonas sp, yang ditunjukkan dengan tidak adanya zona hambat pada daerah sekitar sumur yang berisi aquades tersebut. Larutan pembanding ciprofloxacin $50 \mu \mathrm{g} / 50 \mu \mathrm{l}$ memiliki zona hambat terhadap pertumbuhan Pseudomonas sp.

Pada larutan uji daun mayana jantan konsentrasi $20 \%$ telah menunjukkan adanya efek penghambatan terhadap pertumbuhan Pseudomonas $s p$. dan terus meningkat saat konsentrasi larutan uji ditingkatkan.

Hasil pengamatan pada tabel 2 menunjukkan, efek antimikroba ternyata makin meningkat dengan adanya peningkatan konsentrasi larutan uji berturutturut dari $20 \%$, 40\%, 60\%, 80\% dan 100\%. Hal ini menunjukkan bahwa ada hubungan 
positif kuat antara konsentrasi dan zona hambat. Hubungan ini dapat dilihat pada gambar 2. Artinya, larutan ekstrak daun mayana jantan (Coleus atropurpureus benth) dengan ekstraktor etanol memiliki efek antimikroba terhadap Pseudomonas sp. Dari data semua tabel di atas, dapat ditunjukkan bahwa urutan kekuatan aktivitas antimikroba laurtan uji konsentrasi $100 \%$, 80\%, 60\%, 40\%, 20\%.

Berdasarkan hasil penelitian didapat bahwa ekstrak daun mayana jantan (Coleus atropurpureus benth) memiliki kemampuan antimikroba terhadap kedua bakteri uji. Hal ini disebabkan adanya zat aktif yang terkandung dalam daun mayana jantan. Zat aktif yang terkandung dalam ekstrak daun mayana jantan yang kemungkinan dapat menghambat pertumbuhan bakteri yaitu: minyak atsiri, tanin, flavonoid, dan eugenol. ${ }^{12}$ Minyak atsiri dapat digunakan sebagai antibakteri karena mengandung gugus fungsi hidroksil dan karbonil yang merupakan turunan fenol. Turunan fenol ini akan berinteraksi dengan dinding sel bakteri, selanjutnya terabsorbsi dan penetrasi ke dalam sel bakteri, sehingga menyebabkan presipitasi dan denaturasi protein, akibatnya akan melisiskan membran sel bakteri. ${ }^{13}$ Tanin secara topikal digunakan sebagai astringent untuk pengobatan luka bakar, ulcers, inflamasi kronik dari mukosa membran sebagai obat untuk diare persisten. $^{14,15}$ Zat ini larut dalam air, alkohol, gliserol, dan tidak larut dalam eter, kloroform. Flavonoid dapat meningkatkan proses mitogenesis, interaksi sel, meningkatkan vaskularisasi, mencegah nekrosis sel, dan penyembuhan jaringan luka. ${ }^{16,17}$ Eugenol merupakan cairan yang berwarna kuning pucat, tidak larut dalam air tetapi larut dalma alkohol, chloroform, dan eter. Eugenol digunakan sebagai antiseptik oleh dokter gigi. $^{18,19}$

Sekalipun memiliki kemampuan antimikroba, belum berarti bahwa ekstrak daun mayana jantan disebut zat antibiotik karena belum adanya standar resistensi dan penilaian kepekaan bakteri. Perbandingan ukuran zoa terang yang terbentuk pada larutan ekstrak lebih kecil dari ciprofloxacin sebagai kontrol positif.

Kemampuan antimikroba yang terdapat pada ekstrak daun mayana jantan (Coleus atropurpureus benth) tidak hanya terbatas pada kedua bakteri uji yang dipakai pada penelitian ini tetapi mungkin masih memiliki kemampuan antimikroba terhadap bakteri lain atau mikroba yang lain.

\section{SIMPULAN}

Larutan uji ekstrak etanol daun mayana jantan (Coleus atropurpureus benth) memiliki kemampuan antimikroba. Hal ini ditunjukkan dengan adanya daya hambat pada media kultur bakteri. Larutan uji ekstrak polar daun mayana jantan (Coleus atropurpureus benth) mempunyai kemampuan antimikroba terhadap pertumbuhan Streptococcus sp. dan Pseudomonas sp. dari setiap dosis dalam ukuran kekuatan terbesar $100 \%$, diikuti dengan $80 \%$, $60 \%$, 40\%, dan $20 \%$.

\section{SARAN}

1. Perlu dilakukan penelitian lebih lanjut mengenai efek antimikroba dari daun mayana jantan (Coleus atropurpureus benth) terhadap bakteri lain.

2. Perlu dilakukan uji in-vivo untuk menentukan dosis toksis, dosis letal, dan efek toksik (uji toksisitas), serta efek farmakodinamika lain dan efek sampin dari ekstrak daun mayana jantan (Coleus atropurpureus benth) baik yang polar dan non polar.

3. Perlu diadakan uji fitokimia zat berkhasiat antimikroba dari daun mayana jantan (Coleus atropurpureus benth).

\section{UCAPAN TERIMA KASIH}

Ucapan terimakasih disampaikan pada semua pihak yang baik secara langsung maupun tidak langsung telah menumbuhkan ide atau gagasan dalam pemikiran penulis sehingga dapat menyelesaikan artikel ini.

\section{DAFTAR PUSTAKA}

1. Ditjen POM. Parameter Standar Umum Ekstrak Tumbuhan Obat (1st ed). 
Jakarta: Departemen Kesehatan RI, 1999; p. 3-5, 10-11.

2. Radji M. Mikrobiologi. Jakarta: Buku Kedokteran ECG, 2011; p. 10.

3. Djide dan Sartini. Dasar-Dasar Mikrobiologi Farmasi. Makasar: Lephas, 2008; p. 24.

4. Dalimartha S. Atlas Tumbuhan Obat Indonesia (2nd ed). Jakarta: Trubus Agriwidya, 2007; p. 221.

5. Syamsuhidayat SS dan Hutapea JR. Inventaris Tanaman Obat Indonesia. Jakarta: Departemen Kesehatan RI, 1991; p. 176.

6. Gunawan D dan Mulyani S. Farmakognosi. Jakarta: Swadaya, 2004; p. 56.

7. Lay B.W dan Hastowo S. Mikrobiologi. Bogor: IPB, 1992; p. 78.

8. Siregar S.F. Uji Aktivitas Antibakteri Ekstrak Etanol dan Air Rebusan Kulit Batang Ingul (Toona sinensis M. Roem) Terhadap Beberapa Bakteri [skripsi]. Medan: Fakultas Farmasi USU, 2009.

9. Victor L. Antibiotics in Laboratory Test. USA: The Williams and Wilkins Company, 1980; p. 181.

10.Davis W.W and Stout T.R. Disc Plate Methods of Microbiological Antibiotic Assay. Massachussets: Microbiology, 1971; p. 659-665

11.Dirjen POM. Pengawasan Obat Tradisional. Jakarta: Depkes RI, 2000; p. 9-12.

12.Kusuma F.R, Zaky B.M. Tumbuhan Liar Berkhasiat Obat. Jakarta: Agromedia Pustaka, 2005; p.1-7.

13.Tarwiyah, Minyak Atsiri [homepage on the internet]. c2001 [updated 2013 Apr 1; cited 2015 Oct 27]. Available from: http://www.ristek.go.id/Matsiri.pdf.

14. Merchandetti M. Wound Healing and Repair. Emedicine [homepage on the Internet]. [updated 2009 Mar 13; cited 2015 Oct 27]. Available from: http://emedicine.

medscape.com/article/1298129overview\#showall.

15.Ajizah A. Sensitivitas Salmonella Typhimurium Terhadap Ekstrak Daun Psidium guajava L. Bioscientiae [skripsi]. Medan: Fakultas Kedokteran USU, 2004; p.31-38.

16.Syarfati, Eriani K, Damhoeri A. The potential of jarak cina (Jatropa multifida L.) secretion in healing new-wounded mice. Jurnal Natural. 2011. p.11(1):169.

17.Argamula G. Aktivitas sediaan salep ekstrak batang pohon pisang ambon (Musa paradisiaca var sapientum) dalam proses persembuhan luka pada mencit (Mus musculus albinus) [skripsi]. Bogor: Fakultas Kedokteran Hewan, Institut Pertanian Bogor, 2008; p.32-9.

18.Priantojo. Antiseptik sebagai obat kumurperanannya terhadap pembentukan plak gigi dan radang gusi. Cermin Dunia Kedokteran, 2002; p.28-35.

19. Matsuura T, Kohada A, Yamamoto T, Miyake Y, Akagawa Y, Suginaka H, et al. High incidence of Staphylococcus aureus from dentures and tongues of maxillary resection patients. Nagasaki: Igaku-Shoin, 2007; p.12, 353-354. 